\title{
Tráfico de mulheres nas portarias das prisões ou dispositivos de segurança e gênero nos processos de produção das "classes perigosas"*
}

\author{
Natália Corazza Padovani**
}

\section{Resumo}

Neste artigo, argumento sobre a centralidade das tecnologias de gênero na gestão das entradas e visitas, bem como da vida, nas prisões. Considerando as portarias das penitenciárias uma fronteira, um checkpoint, relaciono os atravessamentos por elas com as historiografias das produções sobre fronteiras nacionais acionadas pela literatura feminista reconhecida como "póscolonial" e transnacional. A partir dessa relação, o artigo segue num teor anedótico, demonstrando como as potentes críticas feministas acerca da noção de "tráfico de mulheres", ao serem deslocadas para as filas das visitas e demandas de entradas nas prisões aqui descritas, contribuem para as análises sobre dispositivos de segurança e gênero na produção de narrativa de saber e poder das prisões femininas.

Palauras-chave: Gênero, Processos de Estado, Prisões, Feminismos, Dispositivo de Segurança, Fronteiras.

* Recebido em 25 de abril de 2017, recebido em 13 de novembro de 2017. A Adriana Vianna e Laura Lowenkron, agradeço pela oportunidade de produzir as reflexões que aqui apresento, bem como pelo aceite para submetê-las a este dossiê dos cadernos pagu. Agradeço a Adriana e Laura, ainda, pelas leituras e contribuições. De mesmo modo, agradeço à Adriana Piscitelli e ao nosso grupo de 2017 - Ana Paula Luna Sales, Anna Paula Araújo, Carol Pavejau Delgado, Domila Pazzini, Lauren Nathaly Zeytounlian, Jessica Gutierrez, Luiza Terassi Hortelan, Raquel Banuth e Tiago Vaz - pelas primeiras leituras deste texto. À Cilmara Veiga, Larissa Nadai e Pedro Oliveira Souza agradeço pelas revisões sempre carinhosas. A Luciana Bueno e Iara Beleli agradeço pela paciência e pelos prestimosos auxílios.

** Pesquisadora do Núcleo de Estudos de Gênero-Pagu/Unicamp, Campinas-SP, Brasil.nataliacorazzapadovani@gmail.com 
Trafficking Of Women In Prisons Entrances Or Security And Gender Devices In The Production Of "Dangerous Classes"

\begin{abstract}
In this article, I argue that gender is a central technology by which prison is administered. Considering penitentiaries entrances as borders, as checkpoints, I make a connection between the act of crossing a prison entrance with the historiographies of national borders produced by "postcolonial" and transnational feminist literature. From this connection, the article follows an anecdotal tenor, wherewith I aim to demonstrate how feminist critiques focused on the notion of "trafficking of women", may contribute to the analysis of the security and gender devices articulation in the production of power-knowledge discourse on women's prisons.
\end{abstract}

Keywords: Gender, State Practices, Prisons, Feminisms, Security Device, Borders. 


\section{Uma anedota: sobre "o" gênero (ou o nada genérico) da prisão}

Em 2001, ainda como aluna do primeiro ano de graduação da UNESP de Marília, tive a oportunidade de, junto com uma amiga, ${ }^{1}$ entrevistar funcionários e presos da penitenciária masculina situada naquela cidade sobre o tema da "conversão religiosa". A atividade de pesquisa seria utilizada como trabalho de conclusão de curso da disciplina Antropologia I. Como resultado daquelas primeiras incursões no campo das prisões, minha amiga e eu destacamos o nó estabelecido entre "crimes sexuais" e "conversão religiosa na prisão". Afinal, todos os presos que participaram de nossa pesquisa e que haviam se convertido a alguma religião durante o cumprimento de suas penas, haviam sido acusados por crimes de "estupro" ou "atentado violento ao pudor". 2

1 Maria Clara Araújo foi minha colega de turma na graduação em Ciências Sociais da Universidade Estadual de São Paulo, UNESP/Marília. Assim como eu, Clara trancou o curso para prestar transferência para outra universidade. Enquanto eu terminei minha graduação na Universidade de São Paulo/USP em 2008, Clara formou-se em jornalismo pela Universidade Federal Fluminense, em Niterói-RJ. Atualmente, trabalha no Instituto Brasileiro de Análises Sociais e Econômicas - IBASE. Nunca canso de agradecer a Maria Clara por compartilhar das minhas primeiras incursões no campo prisional.

2 No ano de 2009, ocorreu a mudança da lei que considerava "estupro" $e$ "atentado violento ao pudor" dois crimes diferentes, apesar de correlatos. O crime de estupro referia-se à penetração vaginal, enquanto que o de "atentado violento ao pudor" a qualquer outra prática de violação sexual, como penetração anal. Em 2001, no período da pesquisa sobre conversão religiosa na penitenciária masculina da cidade de Marília, vigorava a distinção entre os tipos crimes "estupro" e "atentado violento ao pudor". Sobre os enredamentos morais e de relações de poder produzidos entre religião, prisão e "crime", autores como Camila Nunes Dias (2008), Patrícia Birman e Carly Machado (2012), bem como Vagner Aparecido Marques (2013) e Eliakim Lucena de Andrade (2014) têm produzido potentes proposições analíticas. As discussões elaboradas pelos autores citados aqui merecem destaque e são absolutamente relevantes e densas. Apesar de reconhecer que toda exposição etnográfica deste artigo apresenta forte relação com os emaranhados entre religião, sexualidade, "crime" e prisão, não poderei focar minhas análises nessa temática. 
Ao receber as alunas da universidade pública da cidade, os funcionários daquela prisão faziam questão de disponibilizar os prontuários dos "pastores de celas", bem como dos "presos convertidos", para nossa apreciação e leitura. Os crimes vinham descritos e impressos em laudas carimbadas com as insígnias das delegacias civis de Marilia e da região. Papéis recheados com narrativas de estupros seguidos de morte no frigorífero de um supermercado, como também com descrições detalhadas das torturas sofridas por uma juíza da vara criminal sequestrada. Tendo em vista que o estupro estabelecia as fronteiras que separavam os "monstros" dos "presos comuns" 3 - acusados por crimes como tráfico de drogas, furto e assalto seguido de morte - a conversão religiosa parecia-nos ter um lugar bem definido nas relações tramadas naquela prisão. Era por meio dela que os "estupradores" se convertiam, ao menos nas relações com as "celas das igrejas", em "arrependidos" ou "possuídos por um demônio". Categorias que os ressignificavam como sujeitos nas redes de ajuda estabelecidas pelos "evangélicos".

Os dados colhidos em campo nos pareciam bastante esclarecedores e satisfatórios. De tal modo que encerramos a pesquisa e entregamos nosso trabalho produzido para a disciplina de graduação. Minha amiga deixou a faculdade de Ciências Sociais pouco tempo depois, enquanto eu, ainda interessada em estudar prisões, mas sem pensar nas problemáticas atravessadas pela "conversão religiosa" da qual a sexualidade parecia ser senão um detalhe, uma causa espúria, passei a ler sobre o tema.

Obras reconhecidas como clássicas na literatura brasileira sobre prisões (Ramalho, 1979; Brant, 1994 e Salla, 1999) decorrem de pesquisas feitas em penitenciárias masculinas. Etnografias de

${ }^{3}$ A escrita deste trecho da anedota faz alusão, ou uma homenagem, a dois trabalhos que debruçam suas análises não só na produção do estuprador como monstro, como também na etnografia do fazer policial mais ordinário. Laura Lowenkron (2015) e Larissa Nadai (2012) oferecem densas análises acerca das tessituras impressas em "autos lavrados" e "documentos confidenciais". Aparatos de Estado que descrevem e constroem o monstro contemporâneo: do "pedófilo" ao "estuprador desconhecido". 
pavilhões de penitenciárias que enfocaram o elemento caracterizado como "ressocializador" nas palavras da Lei de Execução Penal de 1984 e ainda vigente: "o trabalho". Interessada em seguir essa linha de pesquisa, passei a buscar mais referências sobre os processos de trabalho articulados dentro $e$ fora das prisões. Logo me deparei com uma vasta produção sociológica que propunha analisar os "processos de flexibilização" das relações trabalhistas no âmbito do "capitalismo global". Frente àquela minha curta trajetória de pesquisa nas prisões, me pareceu preponderante investigar sobre como as "reestruturações produtivas" incidiam nas oficinas de trabalho montadas nas instituições penitenciárias. Foi desde esse arcabouço que iniciei minhas incursões nos aparelhos que regulam o trabalho prisional no estado de São Paulo.

Minhas visitas à FUNAP - fundação vinculada à Secretaria de Administração Penitenciária do Estado de São Paulo responsável pelos programas de geração de renda e trabalho dentro das penitenciárias paulistas ${ }^{4}$ - iriam, contudo, desmontar a solene amarração teórica com que eu imbuía meu primeiro projeto de pesquisa.

Aos 21 anos, interessada em produzir uma pesquisa sobre um tema "canônico" no campo, me apresentei aos gestores responsáveis pela implementação de oficinas de trabalho nas prisões paulistas. Naquela ocasião, sequer havia pensado em localizar meu trabalho etnográfico nas instituições prisionais que merecem ser nomeadas com a especificação de gênero "feminina". Não, eu queria estudar "prisão de verdade" desde um "objeto de estudo de verdade". Eu queria estudar prisão, aquela que não precisa da especificação de gênero, pois, por ser masculina, é sempre genérica (Beauvoir, 1967).

4 A Fundação Professor Doutor Manoel Pedro Pimentel, ou FUNAP, foi instituída pelo Governo do Estado de São Paulo por meio da Lei n ${ }^{\circ} 1.238$, de 22 de dezembro de 1976. É uma fundação vinculada à Secretaria de Administração Penal e tem como atribuições a gestão das assistências jurídicas, assim como dos programas de educação, da cultura, de capacitação profissional e de trabalho nas penitenciárias do estado se São Paulo. Ver: www.funap.sp.gov.br. 
O que não era/não é genérico, contudo, eram/são os corpos postos em relação pelo meu pedido de pesquisa à Secretaria de Administração Penitenciária. Pelo lado dos gestores dos aparelhos de Estado, era eu uma menina branca, estudante de Ciências Sociais da Universidade de São Paulo, ${ }^{5}$ que não poderia entrar sozinha em uma prisão de verdade, sem gênero: masculina. Segundo os gestores, quer dizer, as gestoras - pois quase todas elas eram mulheres - ao entrar em uma prisão eu estaria correndo um risco desnecessário. Diziam elas que "os homens eram mais monstruosos que as mulheres" e que, inclusive por isso, a maior parte das oficinas de trabalho eram implementadas nas prisões femininas. Diziam que os empresários tinham menos medo de entregar às mulheres ferramentas e recursos, como tesouras, alicates e facas. Por que então eu correria o risco de estudar oficinas de trabalho em uma prisão quando a maior parte delas estava nas prisões femininas?

Buscando um objeto de pesquisa quase acético $e$ consolidado pela literatura, mais uma vez me deparei com o termo "monstruoso". Dessa vez, ele não se encadeava diretamente à violência sexual, mas sim aos atributos de masculinidade socialmente articulados aos sujeitos presos categorizados como pobres, negros, violentos e agressivos. Em minha relação com eles, o estupro era posto no que não era falado pelas agentes da FUNAP, mas atualizado pelo atributo da "monstruosidade" que colocava a violência sexual à baila pela fantasmagoria historiográfica que permanentemente produz fronteiras entre corpos femininos brancos e masculinos negros (Moutinho, 2004; McClintock, 2010; Davis, 2016). A monstruosidade, aqui, referia-se à normalidade dos atributos de gênero e sexualidade que, por fim,

${ }^{5}$ Como explicitado na primeira nota de rodapé deste artigo, minha graduação foi iniciada na UNESP de Marília e continuada, a partir de 2003, na Universidade de São Paulo/USP. Minha Iniciação Científica teve a cuidadosa e atenta orientação do Professor Ruy Gomes Braga Neto. Contei, ainda, com as gratas conversas e trocas com a Professora Maria Helena Oliva Augusto. 
produzem a instituição prisional. Esta nunca é genérica, nunca é sem gênero. Antes, a prisão é sempre masculina, negra e pobre ${ }^{6}$.

A resposta das gestoras, portanto, não fazia referência às oficinas de trabalho. Antes colocava meu corpo, ou melhor, o corpo de uma menina branca de 21 anos e estudante da USP, em relação aos corpos que informam a produção da prisão e da prisão feminina. Todos tramados por classe, gênero, raça, sexo. A resposta das gestoras me falava de como gênero e sexualidade eram capilarizados na organização do trabalho e de demais "direitos e deveres" listados na Lei de Execução Penal. Era a resposta das agentes da FUNAP, contudo, que abriria minha trajetória de pesquisa. Por fim, através dela, eu entrei pelos portões da penitenciária feminina do Tatuapé ${ }^{7}$, onde passei dois anos acompanhando os processos de trabalho nas oficinas de costura de tapetes, embalagem de aparelhos de rádios para carros, relógios medidores de água e utensílios hospitalares. Atividades adjetivadas nas falas das presas empregadas nas oficinas, bem como das funcionárias da prisão, como "trabalho de preso". Um adjetivo no masculino genérico.

${ }^{6}$ Apesar de, como demonstrado por Alves (2015), ser o número de pessoas em cumprimento de pena nos estabelecimentos prisionais paulistas, e não só, composto majoritariamente por pessoas negras, dizer que a prisão é uma instituição categorizada como negra e masculina não é dizer que todas as pessoas em cumprimento de pena sejam, ou se reconheçam, como homens negros $e$ pobres. Antes é dizer que a instituição penitenciária é um dispositivo de Estado reiteradamente generificado e racializado por categorizações de masculinidade assim intersecionadas com raça e classe.

7 A Penitenciária Feminina do Tatuapé foi fechada em 2005 por insalubridade. As presas que cumpriam pena naquela unidade prisional foram, em sua maioria, transferidas para a Penitenciária Feminina de Santana que deixava de ser, naquele mesmo ano, a Penitenciária do Estado ( $\mathrm{PE}$ ). A ausência do gênero neste último nome indica que a Penitenciária do Estado deixava de ser masculina para passar a abrigar "mulheres presas". Os quase cinco mil homens que estavam presos na PE foram transferidos para penitenciárias do interior do estado num processo de "interiorização" das prisões que é densamente analisado por Rafael Godoi (2015). Atualmente, a Penitenciária Feminina de Santana é a maior penitenciária feminina da América Latina. Nela, cumprem pena quase três mil mulheres (ver: Padovani, 2015; Antunes, 2017). 
Por meio da expressão "trabalho de preso", as agentes e as presas das/nas penitenciárias femininas me esclareciam que aquelas atividades remuneradas só existiam dentro da prisão. Mais especificamente, aqueles eram "trabalhos de preso" que existiam com mais recorrência dentro da prisão feminina.

Ao enfocar a pesquisa no "trabalho encarcerado" encontrei, portanto, para além de dados sobre "as pontas da rede produtiva do capitalismo", o fato de que as tecnologias de gênero ${ }^{8}$ também produziam compêndios e projetos "canônicos" sobre ser "o trabalho encarcerado" nas prisóes elemento central - mesmo que estas não recebessem tantas oficinas de trabalho por serem consideradas muito "monstruosas". As assistentes sociais que me levavam para conhecer as oficinas de trabalho da prisão feminina me diziam, por outro lado, das dificuldades em controlar a instituição durante os períodos em que muitas das "meninas" ficavam menstruadas, das dificuldades em atender suas demandas familiares e de "mães", da compaixão que sentiam por aquelas que não eram "criminosas de verdade", mas que haviam sido "enganadas ou influenciadas por seus companheiros", estes sim, "bandidos de verdade". Por parte das "presas", trabalhadoras nas oficinas em que fiz pesquisa, eram as fofocas sobre quem estava namorando quem, as paqueras e brigas de casais que enredavam as horas dos dias trabalhados. O trabalho era atravessado por elos sexuais e afetivos que, desde minhas observações, apresentavamse como absolutamente centrais naquele cotidiano.

Além disso, a implementação (ou não) das oficinas passava pelas tecnologias de gênero que situavam diferentemente as prisões e as prisóes femininas, inclusive na produção acadêmica sobre o campo. Essa percepção da pesquisa decorria do modo como minha "localização social" (Mahler; Pessar, 2001) fora

8 Teresa de Lauretis (1994) desenvolve a expressão "tecnologia de gênero" num texto que imprime crítica, mas também avanço, à análise acerca do como os corpos de "homens e mulheres" são produzidos segundo expectativas que transcendem o sexo, ou os "dispositivos da sexualidade". Segundo a autora, gênero é um conjunto de efeitos produzidos nos corpos, comportamentos $e$ relações, por meio de tecnologias políticas. 
agenciada em meu processo de deslocamento para o campo etnográfico das prisóes desde categorizações raciais, de classe e de gênero. Através dessas categorizações, as gestoras da FUNAP tramaram, comigo, minha inserção etnográfica na prisão feminina.

Desde os "estupradores convertidos" da prisão masculina de Marília até as oficinas de trabalho implementadas para as "mães" da Penitenciária Feminina do Tatuapé, e não para os "monstros" das prisóes, era sobre sexualidade e gênero como dispositivos de governamentalidade ${ }^{9}$ de que estava sendo falado. Sobre corpos brancos $e$ femininos a serem protegidos dos corpos negros encarcerados, socialmente categorizados como monstruosos pela permanente fantasmagoria da violência e do abuso sexual. Era disso que falava a negativa de minha entrada nas prisões masculinas - nada genéricas - e o deferimento de minha pesquisa nas oficinas de trabalho das penitenciárias femininas. Oficinas nas quais o trabalho estava longe de ser elemento central. Antes era a maternidade, a afetividade, a sexualidade e o "passar o tempo na prisão" que impulsionavam o emprego naquelas "precárias" (Hirata 2009) linhas de produção (Espinoza, 2003; Padovani, 2006; Lago, 2014).

Naquele ano de 2003, as agentes da FUNAP indeferiram minha circulação por entre os corredores onde habitavam (habitam) homens monstruosamente encarcerados nas penitenciárias de São Paulo. O indeferimento objetivava proteger minha "vulnerável" branquitude feminina frente às masculinidades negras, socialmente localizadas como perigosas. Foram, senão as mesmas, outras agentes de um mesmo processo de Estado que, dez anos depois, em 2013, despiram-me sobre o espelho do

9 Pelo termo governo, Foucault (2008) busca mostrar como se constituiu ao longo do século XIX uma nova governamentalidade (nova razão de Estado) que tem o poder pastoral (século XV e XVII) - uma arte de conduzir, dirigir, levar, gerir, controlar e manipular os homens - como pano de fundo. Assim, por técnicas de governo devemos entender um conjunto de instituições, procedimentos, análises, reflexões, cálculos e táticas que permita o exercício de um tipo específico e complexo de poder, e que tem por objeto principal a população. 
cubículo reservado para as revistas das visitas familiares na Penitenciária Feminina do Butantã. Como visita familiar de presa, à minha feminilidade eram agregados outros sentidos.

Pela primeira vez ia entrar em uma prisão brasileira pela fila da visita familiar. ${ }^{10}$ Tendo em mãos minha cédula de identidade nacional (original e xerox), comprovantes de residência e de antecedentes criminais, bem como dois tupperwares transparentes recheados com as saladas $e$ as frutas frescas que me haviam sido encomendadas pela amiga que eu iria visitar - uma interlocutora

${ }^{10}$ Como exponho em minha tese de doutorado, de 2010 a 2014 fiz trabalho de campo em diversas prisões e módulos prisionais femininos nas cidades de São Paulo e de Barcelona. Nesta última, o campo realizado, principalmente durante o período de novembro de 2011 a março de 2012, foi feito a partir da intermediação de brasileiras egressas, ou em regime semiaberto e liberdade condicional, que conheci do lado de "fora" da prisão. Foram elas que me apresentaram ao Padre Jesus, capelão das unidades femininas das penitenciárias de Barcelona. Com ele, fiz as primeiras incursões etnográficas nos módulos prisionais femininos de regime fechado da capital catalã. A partir dessas primeiras idas à penitenciária de Brians, conheci brasileiras que lá cumpriam pena em regime fechado e que colocaram meu nome em seus "rols de visitas familiares". Desse modo, o campo nas prisões de Barcelona foi, em grande parte, feito nas visitas familiares. No tocante à pesquisa realizada nas prisões femininas paulistas, tendo iniciado meu campo como pesquisadora ainda em 2003, passei a atuar como voluntária na Pastoral Carcerária que faz visitas semanais às penitenciárias de todo o estado. Como voluntária, ou "agente pastoral", realizava visitas semanais nas penitenciárias femininas de Santana e da Capital. Nesta última, tinha ainda autorização da Secretaria de Administração Penitenciária e da Juíza Corregedora para a realização de minha pesquisa de doutorado. O longo processo de trabalho de campo, todavia, fez com que eu tecesse vínculos de afeto $e$ amizade com diversas interlocutoras que, contudo, eram transferidas das penitenciárias onde eu realizava visitas como pesquisadora ou voluntária. Fui, assim, colocada em "rols de visitas familiares" por interlocutoras de pesquisa do campo realizado no Brasil. As interlocutoras que me inscreveram em seus rols de visitas familiares no Brasil eram espanholas. Como suas famílias estavam na Espanha e elas estavam presas no Brasil, eu, realizando campo nos dois países, tornei-me uma ponte entre elas e seus familiares. Todo esse processo está detalhadamente descrito em minha tese de doutorado (Padovani, 2015). 
de minhas pesquisas de mestrado e doutorado quem, ao longo dos anos de etnografia, tornou-se uma grande amiga - peguei a estrada em direção à Rodovia Raposo Tavares, quilômetro 19,5.

Os portões principais da Penitenciária Feminina do Butantã estavam abertos. Teria de passar pelos guichês para entregar meus documentos e depois passar pela revista. O domingo já havia amanhecido quente e o sol ardia aos que, como eu, esperavam para entrar na penitenciária às nove horas da manhã. A fila não estava grande. Diferente do que costumeiramente via ocorrer nas penitenciárias masculinas ou na Penitenciária Feminina de Santana, ${ }^{11}$ onde familiares começam a acampar na entrada desde quinta-feira para guardar bons lugares na fila $e$ assim terem mais tempo de visita aos domingos com filhas, esposas, maridos, mães $e$ pais, em Butantã as pessoas chegavam aos poucos $e$ vagarosamente.

Todos levavam sacolas transparentes parecidas com aquelas que armazenam edredons à venda nos mercados. Só eu levava apenas os dois tupperwares. Na minha frente, uma senhora carregava em uma mão a sacola com potes contendo macarrão, frango frito, frutas e almôndegas. $\mathrm{Na}$ outra, um menino de aproximadamente dois anos. Chegamos ao primeiro guichê onde entreguei a papelada necessária para me afirmar no rol das visitas daquela unidade prisional. A agente de segurança que recolheu os documentos informou-me que poderia entrar naquele dia, porém, para as próximas vezes teria de aguardar a confirmação de autorização da minha entrada pela direção da unidade que iria, caso minhas visitas fossem deferidas, produzir uma carteirinha com a qual eu deveria apresentar-me aos domingos naquele mesmo guichê. Carteirinha que a senhora à minha frente e o senhor logo atrás de mim já entregavam.

\footnotetext{
11 Pelo fato de a Penitenciária Feminina de Santana ser a maior penitenciária feminina da América Latina, com aproximadamente duas mil e quinhentas pessoas distribuídas em seis raios dos três pavilhões de moradia, a quantidade de visitas é bem maior do que a de outras unidades penitenciárias femininas da cidade e do estado de São Paulo.
} 
Passamos pelo vão de uma porta em que havia só o batente. Na sala seguinte, havia uma esteira de raios-x e um detector de metais. Entregamos as sacolas e os potes a uma das agentes de segurança responsáveis pela revista daquele dia. Ela os abria e revistava toda a comida. Depois era a nossa vez. A mesma agente de segurança nos encaminhava, um por um, aos vestiários que ficavam atrás do balcão e da esteira de raios-x. Homens para um lado, mulheres para outro. Naquele ponto, como já sabíamos o que teríamos de fazer, tiramos todas as peças de nossas roupas. A senhora que continuava segurando o menino, também tirou as roupas e a fralda dele. Nuas, entregamos nossas roupas à agente de segurança que iria revistá-las, enquanto isso, individualmente, cada uma entrou em uma das pequenas cabines de alvenaria fechadas com cortinas verdes escuras. Mesmo tecido do uniforme das presas em regime semiaberto ${ }^{12}$ no estado de São Paulo, $e$ utilizado pelas presas em cumprimento de pena na Penitenciária Feminina do Butantã.

\footnotetext{
${ }^{12}$ Regime semiaberto é uma progressão de pena. A pessoa sentenciada cumpre parte da pena em regime fechado e, após este, passa para o regime semiaberto. O tempo da pena a ser cumprido em regime fechado depende do tipo de crime do qual a sentenciada é acusada - se crime comum, hediondo ou equiparado a hediondo, tal como é definido o "tráfico de drogas" (Ver: Lei 11.343/06, artigo 33). São definidos como hediondos pelo Código Penal os crimes de homicídio doloso, estupro, assalto seguido de morte e sequestro, por exemplo. De acordo com a redação do artigo $5^{\circ}$ XLIII da Constituição, assim como aos acusados de cometerem crimes hediondos, aos acusados por tráfico de drogas são vetados os direitos de fiança e indulto. A progressão ao regime semiaberto é atribuída aos sentenciados pela Lei de Drogas, após cumprimento de 2/5 do tempo da pena em regime fechado. Aos acusados de crimes comuns, como furto, assalto $e$ estelionato, a progressão ao regime semiaberto pode ocorrer após o cumprimento de $1 / 6$ do total da pena em regime fechado. Importante salientar, contudo, que a progressão de pena depende de avaliações de comportamentos das presas produzidos pelas assistentes sociais de cada unidade prisional, assim como do julgamento dos juízes da vara de execução criminal. Ter cumprido o tempo necessário de pena em regime fechado não é, portanto, único requisito para a progressão. A Penitenciária Feminina do Butantã é uma unidade penal de cumprimento do regime semiaberto.
} 
No chão, o espelhinho sem moldura e com manchas de oxidação. A agente de segurança que havia ficado com minhas roupas afastou a cortina e entrou na cabine. Pediu que eu ficasse de frente e levantasse os braços, depois de costas. Por fim, pediume que agachasse sobre o espelho e abrisse as pernas o máximo possível. "Agora tosse!"; eu tossi; "mais uma vez"; tossi; "de novo"; tossi. Ela entortou a cabeça como se procurasse alguma coisa ainda mais dentro de mim e pediu que todo o processo recomeçasse. Repeti, agachei e tossi mais três vezes sobre o espelho enquanto segurava minhas pernas e meu corpo totalmente abertos. Ela enfim ficou satisfeita. Disse que poderia me vestir enquanto entregava minhas roupas. Vesti-me. Quando saí da cabine para buscar as saladas e as frutas prometidas à amiga que iria visitar, a agente de segurança para quem eu havia entregado os documentos no primeiro guichê me abordou: "acho que eu te conheço"; "pode ser", respondi; "você já fez visita aqui?"; "não, é a primeira vez"; "mas você já vez visita em outras unidades. Você não é da Pastoral Carcerária?"; "sim, sou"; "olha só, hoje você pode entrar, mas depois vai ter de decidir. Ou é família, ou é Pastoral. As duas coisas, não pode!"; assenti e agradeci. Fui em direção ao pátio onde era esperada pela interlocutora/amiga com quem seguiria a fazer pesquisa, visitas, afeto $e$ antropologia. A transgredir, bem como reproduzir $e$ agenciar as fronteiras que esquadrinham "pesquisadoras", "voluntárias", "presas", "familiares".

$* * *$

Como descrevo em minha tese de doutorado (Padovani, 2015), minha trajetória em relação às penitenciárias femininas de São Paulo, começada em 2003, desdobrou-se para a atividade voluntária de "agente" da Pastoral Carcerária ${ }^{13}$ e, como não

${ }^{13}$ A Pastoral Carcerária é uma organização civil que, desde 1986, além de prestar serviços religiosos, fiscaliza o funcionamento das penitenciárias de todo o Brasil (e de outros países, tal como Espanha) encaminhando "denúncias de violações de direitos, organizando movimentos, fazendo reivindicações" (Godói, 
poderia deixar de ser, para as redes de afeto, amizade e "ajuda" (Piscitelli, 2011) tecidas com aquelas que cumpriam pena nas unidades prisionais onde eu fazia visitas como "pesquisadora", como "agente pastoral" ou como familia: parte das redes de manutenção da vida. Como também descrevo em minha tese, se as autorizações para realização de trabalho de pesquisa e de "voluntariado" eram restritas a unidades prisionais específicas - no caso a Penitenciária Feminina da Capital e a Penitenciária Feminina de Santana, ambas no bairro do Carandiru, zona norte da cidade de São Paulo - as recorrentes transferências de minhas amigas $e$ interlocutoras não se restringiam a essas duas penitenciárias. Não foi raro que minhas amigas/interlocutoras, em cumprimento de pena, colocassem meu nome em seus "rols de visitas familiares" para que, dessa forma, nós pudéssemos continuar a nos ver: elas recebiam visitas e eu levava a elas notícias de suas famílias que, recorrentemente, estavam em outro país, na Espanha (ver nota de rodapé número 7).

Minha entrada em diferentes unidades penitenciárias deu-se com diferentes registros de estatuto relacional com a prisão: por vezes eu era pesquisadora, por vezes voluntária e por vezes "familiar de preso". Desde os diferentes estatutos relacionais tramados ao longo de minha trajetória com a prisão feminina, experimentei diferentes formas de revista nas portarias das unidades penitenciárias onde ingressava. Não cabe descrevê-las detalhadamente aqui. ${ }^{14}$ Cabe destacar, contudo, que se como

2010:93). A Pastoral Carcerária ocupa, desde 2005, uma das vagas do Conselho da Comunidade que atua junto aos Conselhos Penitenciário de São Paulo e Nacional de Política Criminal e Penitenciária por meio das seguintes atribuições: "visitar, pelo menos, mensalmente, os estabelecimentos penais existentes na Comarca; entrevistar presos; apresentar relatórios ao Conselho Penitenciário e relatórios mensais, com a especificação das contas, ao Juiz da Execução; e, diligenciar a obtenção de recursos materiais e humanos para melhor assistência ao preso ou ao internado, em harmonia com a direção do estabelecimento" (Trecho da Cartilha do Conselho da Comunidade produzido pelo Ministério da Justiça, 2008:19).

${ }^{14}$ Mais uma vez, para os leitores interessados no que tange ao embaralhamento, à transgressão e à articulação das fronteiras entre produção de pesquisa e afeto, 
aluna de graduação da Universidade de São Paulo interessada em estudar oficinas de trabalho nas prisões, meu corpo - feminino $e$ branco - fora alvo de preocupações com minha "segurança" no tocante aos "monstruosos homens presos", já como "visita familiar" minha vagina era aberta, vasculhada, escancarada pelas agentes de segurança do sistema prisional. Como "visita familiar" não havia brancura feminina a ser protegida, antes havia a contaminação de meu corpo em relação à prisão que me penetrava pelo olhar da agente de segurança e que me escurecia. Penetração a qual me deixava, na relação com as agentes de segurança da prisão, menos humana. Nesse sentido, ser "pesquisadora, voluntária e família" era um embaralhamento das identificações de laços com a prisão. Embaralhamento que desafiava a administração prisional que, por sua vez, me dizia: ou familia, ou pastoral ou pesquisadora.

Entrar em uma penitenciária por meio do rol de visitas familiares significava carregar no corpo um vínculo de comprometimento com aqueles que esperam no pátio, para os quais se levam as comidas, com quem são trocados afetos. Ser mãe, avó, esposo, pai, irmã, amiga significa ser a extensão do corpo condenado e não alguém que o defende, como um advogado, ou alguém que o investiga, como o antropólogo. Ser família é estar em posição de justaposição ao preso na relação com os funcionários da prisão. É eclipsá-lo e, portanto, fazê-lo presente (Strathern, 2010) no cubículo da revista íntima. Naquele domingo, a vagina que abaixava sobre o espelho era a vagina de uma amiga de uma presa condenada sob a acusação de tráfico internacional de drogas. Não era minha vagina que estava exposta, antes era a de um corpo produzido pela relação estabelecida entre a prisão e eu. Uma relação que entrelaçava minha amiga e eu fazendo de nós "irmãs": "família".

Aos domingos, as filas das visitas que são montadas diante das penitenciárias femininas (e, arrisco dizer, masculinas) de São

sugiro que consultem, particularmente, primeiro e segundo capítulos de minha tese de doutorado (Padovani, 2015). 
Paulo, abarcam expressões, palavras e todo um idioma produzido sob a égide de relações familiares que não são completamente dependentes de certidões que comprovem "graus de parentesco". ${ }^{15}$ As filas das visitas montadas aos domingos em frente aos portões de entrada das penitenciárias femininas a que visitei, simultaneamente, como antropóloga, voluntária e "familia" são compostas por sujeitos identificados não só pelas carteirinhas de visitantes, mas pelos sacos contendo roupas, pelos potes que guardam comidas, pelos corpos que esperam a hora de tirar as roupas. São esses - corpos, potes, sacos e carteirinhas substâncias (Carsten, 2004) que, tramadas, produzem "redes familiares".

A cena e a rotina da revista projetadas aos corpos dos "visitantes comuns" - como são classificados nas letras do Regimento Interno Padrão dos Estabelecimentos Prisionais do Estado de São Paulo aqueles que diariamente são chamados por funcionários/as e presas/os de "visitas familiares" - enfocam o

\footnotetext{
${ }^{15}$ No Capítulo I, Artigo 22, Parágrafo IV do Regimento Interno Padrão das instituições penitenciárias de São Paulo consta: "receber visitas do cônjuge, da companheira, de parentes e amigos e outras comuns de ambos os sexos, com estrita observância às disposições deste Regimento" (SAP, 2010). Esse trecho explicita uma constante nos manuais que regulam as rotinas prisionais, a de que a despeito de haver um regimento padrão para todas as unidades, na prática, existem precedentes para que autorizações dependam das diretrizes $e$ interpretações de cada diretoria de cada unidade penitenciária específica. Durante as visitas feitas à Penitenciária Feminina de Santana junto à Pastoral Carcerária não era incomum que reclamações acerca das interdições de visitas chegassem a nós. Em algumas dessas ocasiões, a reclamação passava pelo fato de esposa e marido estarem presos, sendo que apenas um dos dois cônjuges tinha mãe ou pai vivo (na maior parte das vezes, mãe), que havia se responsabilizado em levar os filhos do casal para visitá-los nas prisões. A interdição da visita em algumas unidades, majoritariamente masculinas, ocorria em decorrência do responsável pelo menor visitante não ser parente do preso, fato que impedia a visita dos filhos ao longo de toda pena. Por meio de interdições e deferimentos pouco padronizados, regulam-se exercícios de paternidade (mais que de maternidade) nas penitenciárias. Para Regimento Interno Padrão das Unidades Penitenciárias do Estado de São Paulo, ver http://www.sifuspesp.org.br/files/u1/ovo_Regimento_interno_nas unidades_priso nais.pdf .
} 
exame dos orifícios, dos buracos e das dobraduras dos sujeitos revistados em seus fluídos, suas tosses, suas secreções. Em nenhum outro procedimento de revista os corpos são tão requisitados. Pode-se dizer que, nas revistas feitas em voluntários $e$ pesquisadores, são demandados registros de papéis que lastreiem as relações institucionais e pessoais daqueles: se filiados à Pastoral Carcerária ou a outras organizações religiosas e de defesa de Direitos Humanos; se autorizada pela juíza corregedora e pelos demais superiores a fazer a pesquisa. ${ }^{16}$ Pode-se dizer que essas revistas passam por outras formas de controle e de informações que, todavia, não acionam de modo tão radical o corpo como objeto de investigação.

Em análise sobre os usos táticos do corpo nas disputas políticas travadas entre presos políticos e agentes da instituição penitenciária da Irlanda do Norte na década de 1970, Feldman (1991) argumenta que no espelho utilizado para o exame retal, aplicado aí aos condenados e não a seus familiares, o que se faz ver é o efeito ritual de reorganização das hierarquias de força nas quais estão postos quem observa e quem é observado. Segundo esse autor, o espelho de inspeção retal é o objeto que teatraliza a centralidade da observação recaída a determinados corpos (e de que modo) na organização prisional. Por meio dessa inscrição, Feldman não pretende elucidar posicionamentos de opressão/dominação. Antes, o autor procura ilustrar que os feixes incididos sobre o espelho refletem as cadeias relacionais que produzem os corpos nus dos prisioneiros $e$ os corpos uniformizados dos guardas. Ambos resultantes dos efeitos acumulativos das trocas de forças a eles aplicadas. Assim são os corpos expostos no cubículo da revista íntima da Penitenciária Feminina do Butantã. O espelho que reflete ânus, vaginas e pênis, também refrate os olhos atentos do observador. São esses os

\footnotetext{
${ }^{16}$ Para etnografias de documentos e análises acerca de como documentos são tramados nas teias de governamentalidade e processos de Estado, bem como de identificação, sugiro fortemente: Peirano, 2011; Ferreira, 2013; Lowenkron e Ferreira, 2014; Vianna, 2014.
} 
corpos das relações que transformam "visitas comuns" em "visitas familiares". Nós, transacionais solicitados diversamente pelos rituais de exame que produzem e organizam a prática prisional. Uma prática que enreda relações de poder que são emaranhadas pelos atributos de gênero, raça e classe que os produzem.

Se havia uma branquitude feminina a ser defendida dos perigos atribuídos à masculinidade negra em minhas primeiras incursões etnográficas na prisão, no cubículo da revista eu já não era mais tão branca. Era minha vagina, aquela mesma fenda a ser, antes, protegida, agora vasculhada pela relação de afeto declarada com meu nome no rol de visitas familiares. Como Angela Davis (2003) já demonstrou, a prisão, que nunca é genérica, sempre tem raça: a raça e o gênero das "classes perigosas".

\section{Dispositivos de segurança e gênero nos processos de produção das "classes perigosas"}

O argumento da Secretaria de Administração Penitenciária do Estado de São Paulo para a ocorrência das revistas íntimas vexatórias a que familiares estão submetidos nos portões de entrada das prisões repousa na "justificativa" de serem esses procedimentos imprescindíveis para a "manutenção da segurança". Mais especificamente, imprescindíveis para a interdição da entrada de substâncias e objetos proibidos nas prisões - como armas, telefones celulares, cocaína e maconha. Tal argumento é, entretanto, desmontado pelo simples fato de serem familiares os únicos visitantes a passarem por esse tipo de revista. Segundo dados publicados no boletim produzido pela Rede Justiça Criminal em 2014, ${ }^{17}$ dentre 270.871 visitantes familiares de

\footnotetext{
${ }^{17}$ Rede Justiça Criminal é um coletivo de organizações que defendem uma justiça criminal mais justa e questionam as práticas de encarceramento em massa. A rede é composta pelo Instituto de Defesa do Direito de Defesa, Instituto Sou da Paz, Instituto Terra Trabalho e Cidadania, Associação pela Reforma Prisional, Justiça Global Brasil, Conectas Direitos Humanos, Instituto dos Defensores dos Direitos Humanos e pelo Núcleo de Estudos da Violência da USP. Ver: http://redejusticacriminal.org/
} 
nove prisões (incluindo o Centro de Progressão Penitenciária do Butantã), foram registrados somente 88 casos de tentativas de entradas nas prisões portando aparelhos celulares (43) ou drogas (45). Esse número representa $0,034 \%$ do total de visitantes considerado para a realização da pesquisa. Segundo o relatório, não houve registros de tentativas de entrada nas prisões com armas e menos registros de que drogas e celulares estivessem encaixados nas vaginas $e$ ânus dos visitantes do que em roupas $e$ comidas.

Nesse mesmo boletim, a Rede Justiça Criminal argumenta que outros visitantes, tais como advogados e voluntários, não passam pelos procedimentos de revista íntima vexatória. Desse modo, torna-se flagrante a pressuposição fundamental das revistas: a de serem os familiares, sozinhos, responsáveis por levar armas, drogas e celulares para as prisões (Rede Justiça Criminal, 2014:3). Pressuposição insustentável frente ao fato de serem as apreensões de drogas e celulares dentro das unidades prisionais pesquisadas, quatro vezes maiores que as apreensões feitas entre visitantes familiares de presos. ${ }^{18}$

${ }^{18}$ Desde abril de 2016, as revistas vexatórias em mulheres estão proibidas em todos os estabelecimentos penitenciários brasileiros (grifo meu). A Lei 13.271/2016 prevê multa de vinte mil reais em caso de descumprimento, a ser revertida a órgãos de proteção dos direitos da mulher [http://pesquisa.in.gov.br/imprensa/jsp/visualiza/index.jsp?jornal =1\&pagina $=1 \& \mathrm{~d}$ ata=18/04/2016 - data de acesso: 23 de novembro de 2017. Em São Paulo, em 12 de agosto de 2014, foi sancionada a Lei 15.552 que proíbe a revista vexatória dos visitantes nos estabelecimentos prisionais [http://www.al.sp.gov.br/repositorio/legislacao/lei/2014/lei-15552-

12.08.2014.html - data de acesso: 23 de novembro de 2017. A revista, contudo, continua sendo aplicada aos visitantes de muitos estabelecimentos prisionais paulistas até o momento da escrita desta nota, em novembro de 2017. Tal informação foi obtida de conversas recentes com interlocutoras desta pesquisa que, em cumprimento de liberdade condicional ou mesmo sem nunca terem sido sentenciadas/os, fazem visitas às suas mães, pais e maridos em unidades prisionais paulistas. O tema também vem sendo amplamente analisado por Natália Lago, em sua pesquisa de doutorado em andamento no Programa de Pós-Graduação em Antropologia Social da USP, sobre redes de familiares de pessoas presas no Estado de São Paulo (Lago, 2017 mimeo). 
Mas não são os números e as estatísticas que mobilizam o aparato de "segurança" voltado para as redes familiares das pessoas presas pela materialização do exame de seus orifícios. De mesmo modo, não poderiam ser estatísticas e números a respaldar as preocupações das agentes da FUNAP quanto ao corpo branco $e$ feminino da estudante de graduação da USP, no tocante à demanda de sua entrada na prisão que encarcera homens "monstruosos". Portarias das penitenciárias - por onde determinados sujeitos podem passar desde que sob a égide da proteção, enquanto outros devem ser despidos e penetrados pelos aparatos de controle e fiscalização do Estado - são checkpoints (Jeganathan, 2004) ${ }^{19}$ que definem uma fronteira entre "mundão" $e$ "prisão" (Padovani, 2015). Âmbitos sistematicamente conectados pelas mesmas divisas que os separam (Godoi, 2010).

Como bem nos lembram Gabriel Feltran (2011) e Veena Das (1995), fronteiras são fundamentalmente espaços de contato e tensão. Nesse registro, se são as portarias das prisões espaços nos quais se fazem os processos de revista dos sujeitos que delas saem e dos que nela entram, os cubículos de exame vaginal, retal, bem como in/deferimentos para realização das pesquisas ou a falta de fiscalização dos orifícios dos advogados, materializam a "pequena fenda" pela qual "dentro" e "fora" se entrecruzam.

A expressão "pequena fenda" faz referência aos argumentos de Maria Elvira Díaz-Benitez (2013) sobre as tensões produzidas entre erotismo e violência no set de filmagem de pornografia bizarra, mais especificamente de filmes nos quais práticas de humilhação são trabalhadas como fetiche erótico. Segundo a autora, nesses filmes, classe, idade e raça são traduzidos em

\footnotetext{
${ }^{19}$ Pradeep Jeganathan (2004) define checkpoints como pontos de parada que interrompem os fluxos e fiscalizam se os sujeitos em trânsito podem ou não seguir em seus deslocamentos. Seguindo seus argumentos, guichês de fronteiras nos aeroportos ou estradas rodoviárias, por exemplo, são os checkpoints mais evidentes. Catracas de metrô, blitz policiais, acessos (ou interditos) ao atendimento médico ou mesmo os portões das prisões, porém, são checkpoints rotineiros pelos quais sujeitos em deslocamento através das fronteiras devem passar para seguir (ou não) seus percursos.
} 
diferenças corporais de tal modo que desigualdades passam a ser materializadas nas relações sexuais. Díaz-Benitez argumenta que nestes sets são produzidos cenários em que se abre uma "pequena fenda" através da qual a representação do ato sexual se torna violência (Díaz-Benitez, 2013:84). Vale destacar que a produção do argumento dessa autora é tributária do modo como Maria Filomena Gregori (2016) utiliza o termo "fissura" em suas análises sobre mercados eróticos e limites da sexualidade. Segundo Gregori, materiais (e práticas) pornográficas, antes de ameaçarem, expõem as tensões e ressignificações das fissuras das normas de gênero e sexualidade. Ambas as autoras se preocupam com as ranhuras que relacionam "abuso e consentimento" (Gregori), "violência e representação do (ato) sexual" (Díaz-Benitez) por meio de atributos de potência e vulnerabilidade. O modo como essas autoras trabalham tais termos permite pensar as relações por meio das quais dentro/fora da prisão são tensionados pelas próprias fissuras corporais dos que fazem visitas nas penitenciárias $e$ dos que se relacionam com as instituições prisionais.

A vagina que repousa seus fluídos sobre o espelho da revista - essa mesma uma prática de humilhação de Estado que rememora o fetiche erótico, bem como a violenta tensão sexual que respalda a negativa da menina branca de classe média de entrar em contato com os presos "monstruosos" da prisão masculina - é a fissura. É por onde se faz a fenda através da qual são tramados os processos de Estado que edificam a prisão, suas saídas e entradas. Bem como por onde são localizadas $e$ diferenciadas as posições dos sujeitos que com ela se relacionam: se são perigosos e (ou) vulneráveis.

Levando em conta as considerações de Foucault (2008) acerca do "dispositivo da segurança", processos de criminalização dos fluxos populacionais não implicam em aparelhos de controle que impedem os atravessamentos dos sujeitos, mas sim de aparatos de gestão que os conduzem, os localizam e, como não poderia deixar de ser, os diferenciam. Os pontos de parada, como as portarias das penitenciárias, são aparelhos do dispositivo de segurança que esquadrinham os que por eles atravessam 
definindo as "classes perigosas" $e$ as suas "vítimas": criminalizando $e$ vulnerabilizando os fluxos de algumas populações em detrimento de outras. Assim se faz o dispositivo da segurança que recai sobre os corpos despidos dos familiares feitos em orifícios sobre o espelho no cubículo da revista. É desse mesmo dispositivo que trata a negativa do corpo branco, feminino e relacionado aos atributos de uma meninice burguesa, penetrar nos "monstruosos" homens presos nas prisões que, sem falar seu gênero, exalam a raça e a masculinidade que os aprisionam.

Para a compreensão de como operam os "dispositivos da segurança", e a gestão das mobilidades através deles, se faz absolutamente necessário levar em conta como as tecnologias de gênero os fundamentam. Arguir sobre deslocamentos através das fronteiras significa voltar-se para a seara dos imaginários e práticas de produção de ancestralidades e corpos que criam efeitos, noções, sentimentos e pares de antagonismos tensionados entre consentimento e vulnerabilidade, perigo e prazer (Gregori, 2016).

\section{Todas as fronteiras têm gênero: o "tráfico de mulheres"}

Anne McClintock (2010) inicia seu último capítulo do livro Couro Imperial afirmando que "todos os nacionalismos têm gênero". A autora expõe que a ideia de nação como "representação cultural de comunidades imaginadas" depende da construção vigorosa do gênero. Não por acaso, esse mesmo livro de McClintock começa com a imagem do best-seller As Minas do Rei Salomão, no qual algum lugar do sul da África, que não é exatamente localizável, é representado como as "terras virgens" a serem penetradas pelos ingleses brancos. Se no início do livro a autora faz referência a um lugar inexplorado, uma terra "virgem" no sul da África categorizada como feminina e negra (bem dizer), ela o encerra lembrando ao leitor que as terras vazias são sempre povoadas. A produção dos territórios nacionais, entretanto, depende da invenção de um espaço anacrônico pronto a ser semeado, penetrado, explorado, construído. É desde essa historiografia que as nações são criadas como unidades políticas 
contornadas por fronteiras produzidas por tecnologias de violência, embebidas em atributos de gênero e sexuais. Tecnologias nomeadas ironicamente por McClintock como "anjos do progresso".

É também na figura de um "anjo", o "anjo negro" de Nelson Rodriguez, que Laura Moutinho (2004) repousa parte de seu enfrentamento analítico sobre as políticas afetivo-sexuais que produzem limites procriativos $e$ matrimoniais entre brancos $e$ negros no Brasil e na África do Sul. Essas políticas sexuais são técnicas violentas de estabelecimentos das fronteiras das nações, no caso, brasileira e sul-africana. Práticas de produção do sangue $e$ da descendência da raça que figuram como as fronteiras nacionais nos âmbitos domésticos, afetivos e matrimoniais. As análises de Laura Moutinho e Anne McClintock aludem a tensões $e$ disputas entre homens brancos $e$ negros no tocante a exploração, penetração $e$ ao ato de semear mulheres e terras com vistas à produção das fronteiras que estabelecem os filhos $e$ as raças das nações. Os argumentos convergem com as descrições de Veena Das (1995), em Critical Events, no qual a autora demonstra que as fronteiras nacionais entre Índia e Paquistão só são passíveis de serem produzidas por meio dos sequestros, violações $e$ germinações dos corpos das mulheres.

Os argumentos de McClintock, Moutinho e Das fazem ver que as mulheres são os sujeitos e os objetos por meio dos quais as fronteiras nacionais são produzidas. Que as mulheres são incorporadas na política nacional e nos processos de Estado como suas fronteiras. Ademais, segundo os argumentos das autoras feministas recorrentemente nomeadas como pós-coloniais mesmo quando essas são críticas aos usos da nomeação "póscolonial" (McClintock, 2010) -, são justamente os processos de penetração e semeadura dos homens brancos dos impérios que produzem não só fronteiras nacionais, fundamentadas em categorizações e atributos de gênero, como também inventam a raça. Essa invenção 
tornou-se central não só para a autodefinição da classe média, mas também para o policiamento das "classes perigosas': a classe trabalhadora, os irlandeses, os judeus, as prostitutas, as feministas, os gays e as lésbicas, os criminosos, a turba de militantes e assim por diante (McClintock, 2010:20).

Gênero e raça, justapostos e mutuamente produtos um do outro, localizam, portanto, os sujeitos em classes médias ou perigosas. Localizações densamente alinhavadas às produções das fronteiras $e$, consequentemente, ao controle e à criminalização ou não dos trânsitos.

A produção das "classes perigosas" e "vulneráveis" no tocante ao controle dos fluxos populacionais através das fronteiras tem sido densamente analisada por teóricas feministas, principalmente, no que tange à categoria crime "tráfico de pessoas". Isso porque essa categoria passa a ocupar, a partir do início da primeira década do século XXI, centralidade nos debates $e$ implementações de políticas de controle das fronteiras em todo mundo.

As considerações de Kamala Kempadoo (2004) sobre o tema são esclarecedoras. Ao voltar seu olhar para como a noção de "tráfico de mulheres" informou as disputas que atravessaram (e atravessam) a produção da categoria crime "tráfico de pessoas", a autora demonstra que, historicamente, essa categorização se manteve em conformidade com os posicionamentos da corrente feminista Euro-Americana, branca e de classe média. Essa vertente feminista relacionava (ou tem relacionado) prostituição primeiro à ideia de "tráfico de escravas brancas" e, depois, à "escravidão sexual feminina". Sua premissa central é de que a prostituição é impreterivelmente uma forma de violência sexual, bem como são as mulheres vítimas da violência masculina. Nesse sentido, considera-se que o "patriarcado" força as mulheres à prostituição as mantendo em escravidão sexual e violando seus direitos. Mais do que isso, supõe-se que as mulheres nunca entrem livremente em relações sexuais fora do "amor" ou do desejo sexual autônomo. De modo que a prostituição passa a ser entendida 
como uma forma de escravidão sobre a qual não há possibilidade de consentimento.

Os pressupostos feministas brancos e ocidentais, de que fala Kamala Kempadoo, foram objeto de apreciações elaboradas por feministas transnacionais. Essas autoras se voltaram para o modo como os feminismos ocidentais articularam a categoria "mulheres do terceiro mundo" ou "mulheres de cor". Segundo Chandra Mohanty (1986) e Avthar Brah (2006), tais terminologias repousavam na noção de hierarquias geopolíticas entre "primeiro e terceiro mundos". "Primeiro mundo" aparecia como mais desenvolvido por nele as mulheres estarem, supostamente, mais livres das relações de opressão e serem, portanto, sujeitos ativos das relações de trabalho, políticas e familiares: relações emancipatórias. Paralelamente, a categoria "mulheres do terceiro mundo" aparecia como a nomenclatura de um grupo amorfo, préhistórico e pré-relacional. Ao compósito amorfo, nomeado como "mulheres do terceiro mundo", foram atribuídas categorizações de pobreza, subdesenvolvimento, incivilidade e subordinação. Atribuições traduzidas mais recentemente pelo idioma da razão humanitária do Estado (Fassin, 2011) e por setores feministas ocidentais como "vulnerabilidade" (Lowenkron, 2015b; Piscitelli, 2013).

Mais do que isso, se Kamala Kempadoo lembra que os sentidos articulados ao tráfico de mulheres recaíam ao temor da escravidão sexual das mulheres brancas, há, nas articulações contemporâneas do tráfico de pessoas com a vulnerabilidade, uma torção racial. O objeto de preocupação não se revela na figura da escravização das mulheres brancas, mas sim das "vulneráveis" mulheres negras, morenas, asiáticas, ou "de cor" em processos migratórios para trabalharem nos mercados sexuais dos países "brancos" europeus e norte-americanos (Blanchette; Silva, 2011). Tal torção vem respaldada pela perversa relação entre vertentes dos feminismos, discursos humanitários e práticas bélicas dos exércitos nacionais que transnacionalizam aparatos punitivos de Estado por meio da criminalização e da interdição migratória dos homens $e$ das mulheres negros e negras, latinos e latinas aos 
países ao norte da Europa, mas também à Espanha, Portugal e Itália (Piscitelli, 2013). Perversa relação que abre, ainda, precedente e legitima as penetrações militares dos homens brancos nos países muçulmanos, como vêm chamando atenção Lila Abu-Lughod (2002) e Saba Mahmood (2001).

Os feminismos carcerários de que fala Elizabeth Bernstein (2010), ou seja, o modo como a chave da violência sexual tem sido articulada por vertentes feministas em consonância com o marco argumentativo dos direitos humanos e do ativismo religioso - implicando na disseminação e no recrudescimento das agendas punitiva norte-americanas -, são atualizados nas capilaridades dos processos de Estado e regulações das fronteiras. No tocante à pulverização transnacional da agenda do "tráfico de pessoas" e à articulação de noções de "vulnerabilidade" com as mulheres negras, pobres, "do terceiro mundo", há a decorrente criminalização do "sujeito criminoso do tráfico". Este, inescapavelmente categorizado racial e sexualmente como o "monstruoso" homem negro. Por fim, nunca é demais lembrar o modo como Gayatri Spivak (2010:94) ironizou o clamor dos feminismos brancos euro-americanos: "os homens brancos salvando as mulheres de pele escura dos homens de pele escura".

Mas, se desde uma perspectiva transnacional, ${ }^{20}$ os dispositivos administrativos supranacionais, como o Protocolo de Palermo e o tipo crime "tráfico de pessoas", ao serem incorporados aos marcos legais e aparelhos de governo nacionais, atravessam fronteiras sendo ressignificados e deslocados para outros checkpoints que não os guichês dos aeroportos ou postos de fiscalização das entradas e saídas em território nacional, cabe agora voltar para a prisão e para como a noção do "tráfico das mulheres" se reatualiza nas portarias das prisões.

\footnotetext{
${ }^{20}$ Segundo Inderpal Grewal e Caren Kaplan (1999), enquanto a noção de internacional refere-se à soberania dos Estados-nações, o arcabouço transnacional permite que as assimetrias e desigualdades sejam analisadas desde as práticas de subversão e agência dos sujeitos que atravessam as fronteiras. Para as autoras, as teorias e metodologias pós-coloniais viabilizaram os estudos transnacionais com o adensamento dos conceitos de subalternidade e diáspora.
} 


\section{Tráfico de mulheres nas portarias das prisões}

Antes de dar início a este tópico, esclareço que não pretendo analisar, aqui, a ocorrência do crime de "tráfico de pessoas" no alinhavo com o mercado transnacional de drogas. Também não tenho nenhuma pretensão de negar a incidência de circunstâncias nas quais uma pessoa vinculada ao mercado de drogas possa ser também vítima do crime de "tráfico de pessoas" nos moldes do que é prescrito no Protocolo de Palermo e na Lei 13.344/2016, lei de "repressão ao tráfico de pessoas", no Brasil. Ao contrário. Desde minha pesquisa de mestrado (Padovani, 2010) até minha mais recente etnografia com estrangeiras egressas das prisões de São Paulo, acusadas e condenadas pelo crime de "tráfico internacional de drogas" (FAPESP 08142-7), tenho me deparado com situações nas quais parte de minhas interlocutoras narram contextos de vitimização que poderiam ser categorizados como "tráfico de pessoas". Contextos nos quais, à atividade consentida do transporte de drogas somam-se situações de violência física e graves ameaças.

O que analiso no corpo deste artigo, por sua vez, é como a noção de "tráfico de mulheres" tem sido capilarizada pelos repertórios humanitários de defesa das "mulheres encarceradas". Repertórios os quais podem incorrer na corroboração do imaginário de "monstruosidade" reiteradamente atribuído aos "homens negros", sobre os quais recaem tão contundentemente processos de criminalização.

Esse exercício de análise é inspirado em como Angela Davis questiona (1997) os processos discursivos que edificam a instituição punitiva e a "indústria carcerária". Segundo Davis, discursividades que produzem medo e perigo são sempre componentes de racismo. Uma questão que não pode ser tangenciada, assim, é o fato de serem os repertórios sobre opressão e vulnerabilidade parte das tecnologias que inevitavelmente aumentam processos de criminalização $e$ encarceramento: tornam as tecnologias do racismo ainda mais virulentas (Davis, 1997:269). 
No que tange aos argumentos expostos aqui, as formulações de Angela Davis podem ser alinhavadas às análises tecidas por Adriana Vianna (2013). Segundo a autora, a malha de materialidades e crenças que abrem possibilidades para atores, ações e repertórios denunciarem os "direitos" como injustos ou insuficientes, demandando que o Estado "faça direitos", pode implicar a reconfiguração da soberania do Estado como um valor. À demanda do "fazer direitos", operacionalizada nas arenas humanitárias e direcionada para as aparelhagens de Estado, são emaranhadas tecnologias de "desfazer direitos". Ao final, a instrumentalização dessa gramática jurídico-política repousa em um "diagrama de responsabilidades" constituído de modo que se possa considerar com clareza quem é a vítima e quem é o culpado (Vianna, 2013:30).

$\mathrm{Na}$ arena da defesa dos direitos das "mulheres encarceradas", o acionamento da noção do "tráfico de mulheres" pode incorrer no recrudescimento do "desfazer direitos" dos sujeitos diagramados como "culpados", bem como não necessariamente promover direitos às "mulheres", categorizadas como "vítimas" por meio de atributos que as despolitizam. O que proponho fazer aqui, portanto, é provocar a reflexão sobre como $\mathrm{o}$ acionamento de determinados diagramas morais, alinhavados às tecnologias de gênero e aos repertórios do humanitarismo, pode, mais do que quebrar, implicar em virulências racistas e no recrudescimento das tecnologias de criminalização do Estado que edificam as prisões.

Não matou nem roubou, mas foi presa em flagrante. Escondeu no chateaux, o bagulho do amante. O amante saiu e largou o embrulho. Quando a casa caiu tava lá o bagulho. Hoje a vida é na cela. Toma banho de sol. Acompanha a novela e também futebol. No dia de visita, sua mãe vai levar a criança bonita para ela abraçar. O amante saudoso nunca mais foi lhe ver. $\mathrm{E}$ ela nem tem direito a um pouco de prazer. E que venha o alvará pra essa pobre mulher, que um dia 
sairá se Deus quiser (Música "O Bagulho do Amante", Leci Brandão).

Meu marido é Zé Povinho ["trabalhador", não envolvido com o crime]. Ficou um mês sem saber que eu estava presa. Eu falava pra ele que estava viajando. $\mathrm{Na}$ cabeça dele, eu trabalhava na Claro, mas também eu tinha tudo da Claro: uniforme, caneta, prancheta, crachá, até holerite... Ele me achava a maior patricinha do shopping, trabalhadora, boa pra casar. A gente não morava junto, verdade que ele nem era meu marido. Era um peguete de uns quatro meses. Mas quando ele soube que eu vim presa, queria me visitar, aí a gente fez o papel de amásio. Mas eu era a maior bandida, dormia com oitão debaixo do travesseiro, tinha balança, contabilidade, pó e bala, tudo na minha casa. Ele nunca sonhou em ganhar em um mês o que eu ganhava em um dia "trabalhando na Claro". Agora, já falei pra ele, quis ficar comigo vai ter de ficar miudinho. Se pego ele me traindo na rua, mato ele, a mãe dele e a menina. Ele vem me visitar todo domingo. No começo ficava todo tímido, com medo de cadeia. Agora já conhece toda a bandidagem. Traz até recado de marido, mãe, vizinha para as meninas. Outro dia trouxe um pote de comida que uma família da rua pediu para entregar para alguém aqui de dentro. Aí eu disse, "vai ô bandido bananão, depois se é droga que tem nesse macarrão, eu não vou ficar na fila da visita não!". Bandido bananão... quer prova de amor maior que me ajudar na cadeia? Maior prova de amor ficar na fila da visita, trazer comida todo domingo, cuidar do meu pai lá fora... Preciso te contar... maior prova de amor! Ele é o meu bandido bananão! (Caderno de campo. Abril de 2013. Penitenciária Feminina de Santana)

Era cantando a música "O bagulho do amante" que a deputada estadual do PCdoB, Leci Brandão, abria, em 12 de junho de 2012, a audiência pública para debater "a situação das mulheres encarceradas" na Assembleia Legislativa do Estado de 
São Paulo (ALESP). A sessão aberta contou com a presença de especialistas em Direito, integrantes de organizações da sociedade civil preocupadas com o tema e duas egressas do sistema prisional. Naquela tarde, muito se falou sobre as condições degradantes a que as mulheres são submetidas durante o processo de suas execuções penais e, principalmente, acerca do fato de ser o crescimento da "população encarcerada feminina" bastante decorrente do aliciamento a que as mulheres são submetidas por seus namorados e maridos envolvidos com o comércio de drogas.

Nas falas feitas ao microfone da mesa da ALESP, uma situação era apontada como recorrente: a de cônjuges e filhos pedirem para suas esposas e mães "segurarem a droga", ou seja, "segurarem o flagrante" que as levariam presas durante uma blitz policial. A audiência terminou com a fala de uma egressa que havia levado para a Assembleia Legislativa todos os seus quatro filhos, os quais corriam pelas escadas encarpetadas. A egressa dizia que as condições de pobreza e falta de trabalho a que muitas mulheres, grande maioria "mães solteiras", estavam submetidas nas periferias de São Paulo (como também de "outros países"), as faziam recorrer ao mercado de drogas para poderem "alimentar seus filhos". O ponto final de todo o evento foi dado por uma advogada que lembrou o que ela chamou de "conexão perversa" entre diversas redes de tráfico, todas gerenciadas por homens: as redes de tráfico de drogas, de mulheres, de órgãos e de armas. Segundo essa advogada, as mulheres eram "vítimas" dessas redes. Eram elas aliciadas em vários sentidos, pois "uma mulher é capaz de tudo pela sua família" ou por "amor".

Sob aplausos emocionados, Leci Brandão batucou mais uma vez sua música que, segundo uma assistente social ali presente, falava tudo o que seria necessário dizer sobre "mulheres presas" em tão poucas palavras e de modo tão simples. Por meio daqueles versos, as "mulheres presas" eram relacionadas a atributos de vitimização $e$ ingenuidade que se opunham a sagacidade dos "homens" que "se aproveitavam" delas. A vantagem atribuída aos "homens", nessas narrativas, referia-se ao fato de as mulheres se "apaixonarem por eles", ou então, de 
"amarem seus filhos a tal ponto que seriam capazes de fazer qualquer coisa". Nas falas proferidas durante a audiência aberta na Assembleia Legislativa do Estado de São Paulo, as "mulheres presas" eram produzidas por "amores" vinculados ao "sacrifício".

Ao longo de todos os anos em que fiz trabalho de campo em penitenciárias femininas, não poucas vezes escutei narrativas que teciam conexões entre "pobreza", "amor" e "sacrifício". Eram acionadas por assistentes sociais e voluntárias de organizações não governamentais voltadas para o trabalho com "mulheres encarceradas" que me explicavam como "a grande maioria das mulheres" era "levada" por seus companheiros a cometerem crimes. Nos pátios das prisões, bem longe das assembleias legislativas e dos pavilhões administrativos onde trabalhavam as assistentes sociais, ouvia presas falarem sobre seus "casos" com outras presas, sobre seus "casamentos" com seus maridos, esposas, namorados, namoradas, amantes. Nesses relatos, elas às vezes aludiam a como suas relações afetivas as tinham levado para a prisão $e$, por outro lado, sobre como alguns vínculos tornavam mais fáceis os cumprimentos das penas, sobre como por meio deles elas tinham perspectivas de moradia, auxílio material $e$ suporte emocional "dentro/fora" da penitenciária. As narrativas dos pavilhões eram, assim, atravessadas por "sofrimentos" nomeados como "saudades", "medos", "dores físicas", "doenças", mas essas não eram as informações que configuravam o centro de nossas conversas. O sofrimento era mais um dos elementos a ser, contudo, articulado na relação com as mesmas gestoras públicas $e$ advogadas que falavam na ALESP, naquela sessão aberta sobre a "situação das mulheres encarceradas na cidade de São Paulo".

E foi na Penitenciária Feminina de Santana, em abril de 2013, que conheci a "esposa do bandido bananão". A história que ela me contava desde o pátio daquela prisão contrastava terrivelmente com a música cantada e chorada na ALESP naquela tarde. A "bandida" falava que, antes de ser presa, ela vestia o uniforme de funcionária da empresa de telefonia Claro e saía da casa onde morava com o pai para ir, todos os dias pela manhã, ao 
apartamento onde guardava a cocaína que pesava, embalava $e$ distribuía para um segmento do mercado de drogas de São Paulo.

A "bandida" que "dormia com arma debaixo do travesseiro", se fantasiava de "patricinha de shopping, trabalhadora e boa pra casar" com seu esposo "zé povinho", o qual era um "peguete" antes de sua prisão. Foi com a prisão da "bandida" que o "zé povinho" se tornou, pelo suporte dado a ela por meio das visitas, pelos "jumbos" 21 , bem como pelos cuidados que ele passou a ter com o seu pai, o "meu bandido bananão". Afinal, quer maior prova de amor do que ir visitar cadeia todo domingo?

Por mais contrastivas que sejam, as palavras da "esposa do bandido bananão" e a canção de Leci Brandão parecem, entretanto, ecoar uma a outra. Por mais discrepantes que elas pareçam à primeira vista, há algo em ambas que as conecta. $\mathrm{Na}$ música e na fala "o amor" e a relação com os "homens" são acionados. Em uma, articulados com elementos de vitimização e abandono "da mulher", na outra, articulados com a ferramenta privilegiada para a produção de arranjos inéditos na vida da "bandida". Arranjos que a fizeram produzir "amor" pelo "seu bandido bananão". Arranjos que a fizeram produzir os cuidados de ensiná-lo como se portar em relação às outras visitas da cadeia, arranjos vinculados às comidas $e$ às atenções que ela recebia dele e que faziam sua vida na prisão mais fácil. Por fim, foi a partir de seu "encarceramento" que ela havia se tornado "esposa do bandido bananão", o qual não a abandonou perante os percalços da prisão. Amor e sofrimento eram articulados pela esposa do "bandido bananão" como ferramentas produzidas perante o sofrimento cotidiano da pena. Na sessão aberta da Assembleia Legislativa e na letra da música de Leci Brandão, "amor e sofrimento" eram acionados como ferramentas perante os aparelhos estatais.

\footnotetext{
${ }^{21}$ Jumbos são comidas, roupas, utensílios de higiene pessoal e outros objetos/mercadorias enviados para a prisão por correio ou pelas visitas que os familiares fazem às pessoas em cumprimento de pena.
} 
Na ALESP, o "sofrimento" informava a necessidade de produção de políticas públicas específicas para as "mulheres presas": uma ação humanitária.

Em nome de uma ação humanitária, ou ainda, com vistas a "sensibilizar a sociedade para a questão do encarceramento de mulheres", algumas "calamidades" (Kleinman, 2006) relacionadas à prisão feminina têm sido sistematicamente postas sob os holofotes do debate, terminando por invisibilizar problemáticas atreladas à vivência das pessoas em cumprimento de pena nas prisões. Invisibilizar os contextos que permitem a efetivação dessas tragédias. Mais do que isso, têm aberto precedente para a reiteração da categorização de "monstruosidade" vinculada aos "homens presos".

Como argumenta Fassin (2011), os processos da razão humanitária produzem populações vulneráveis as quais são, ainda nas palavras do autor, marcadas pelas categorias de "exclusão" $e$ "sofrimento psíquico". A elas cabe a "invenção do Estado", mais especificamente, a invenção de lugares ou aparelhos de escuta com vistas a colocar os sujeitos desses sofrimentos, "sujeitos vulneráveis", frente a um corpo de gestores públicos que materializa expertises e saberes voltados para o governo das populações. No que tange às penitenciárias femininas, esse corpus de gestão é personificado pelas assistentes sociais, psicólogas, advogadas das defensorias públicas, assim como voluntárias e pesquisadoras que atuam nas Ongs de Direitos Humanos.

Refletir acerca de como o "sofrimento" informa o campo das prisões femininas vincula-se ao modo como Fassin desenvolve suas críticas à razão humanitária, por meio da qual as tecnologias de governo se relacionam com práticas de "compaixão repressiva". Uma compaixão que pode incorrer no recrudescimento dos dispositivos de segurança fortemente atuantes nas fissuras relacionais entre "vulnerabilidade e perigo". Compaixão que, invocada pela retórica da vítima humanitária, termina por ter o efeito de criminalização daqueles que não 
atendem às expectativas atribuídas às vítimas pelos repertórios dos aparelhos de gestão do humanitarismo.

A anedota acerca de como "amor" e "sofrimento" são acionados na música de Leci Brandão, cantada emocionalmente durante a sessão aberta da Assembleia Legislativa de São Paulo e posta em contraste com a forma como as mesmas emoções são articuladas na fala da esposa do "bandido bananão", ilustra a articulação política das emoções nos lugares produtores da instituição prisional $e$, portanto, produtores dos sujeitos por ela "atendidos". A sessão aberta da Assembleia Legislativa de São Paulo é um lugar de escuta em que a exposição de sofrimentos psíquicos que produzem as populações vulneráveis é demandada. Para atender tal demanda, há a necessidade de exposição e definição de uma "classe perigosa" categorizada desde atributos de masculinidade.

O pátio da prisão também pode ser articulado como um lugar de escuta desses mesmos processos, contudo, pode ser "colonizado" (Das; Poole, 2004) pelos sujeitos que o habitam ocupando de modo distinto as ordenações do "sofrimento". Tal "colonização" é dissonante à lógica da razão humanitária por descolar o sujeito de fala do sujeito agregado à vulnerabilidade. No pátio da prisão, sofrimentos e agências não são excludentes como o são na sessão da ALESP. Processos políticos que articulam a "razão humanitária" incorrem na produção de populações a serem por ela governadas desde categorias díspares daquelas as quais os sujeitos vivenciam. Produzem processos aos quais os sujeitos devem responder para que sejam esquadrinhados como vulneráveis e, portanto, passíveis de serem captados pelas práticas humanitárias que governam os sofrimentos.

O exemplo mais evidente desse processo discursivo de produção da vulnerabilidade nas penitenciárias femininas é o acionamento estratégico, feito reiteradamente pelas gestoras $e$ agentes do humanitarismo vinculado ao campo do "encarceramento feminino", de uma história particular na qual uma mulher presa na Penitenciária Feminina de Franco da Rocha, na década de 1990, estava menstruada em uma cela de castigo. 
Durante o período em que esteve detida na cela de castigo, isolada, portanto, do convívio com as demais pessoas em cumprimento de pena naquela unidade, ela não teve acesso a absorventes higiênicos de modo que, segundo contou a um advogado da Pastoral Carcerária, utilizou miolo de pão para conter o fluxo menstrual. A partir dessa história, produziu-se uma narrativa de vulnerabilidade amplamente acionada pelos agentes das "ações humanitárias" voltadas para o campo das prisões femininas. Ela decorre de um acontecimento real, uma situação de tortura que, de outro modo, tem sido invisibilizada pelos usos descontextualizados do "miolo de pão" que, ao lançar todo o foco para o "miolo de pão" e a ausência de absorventes, joga sombra para as situações de castigo a que podem estar submetidas mulheres menstruadas, mas também, homens esmerdeados, meninas parturientes, travestis estupradas com seus cabelos raspados. $^{22}$

Ao longo do tempo em que fiz trabalho de campo em prisões femininas de São Paulo, a menstruação nunca apareceu como uma narrativa de sofrimento central para o cotidiano desse campo. Antes, as duras narrativas de sofrimento falavam acerca do tempo da pena, das incertezas sobre os filhos abrigados ou sob o cuidado de familiares e vizinhos, das saudades da companheira que saiu em liberdade, da ansiedade em saber se poderá voltar a

\footnotetext{
22 Sobre a travesti Verônica que foi estuprada, espancada e torturada pelos policiais do $2^{\circ}$ Distrito Policial do Bairro de Bom Retiro na cidade de São Paulo, ver Renan Quinalha (2015). Sobre Barbara Oliveira de Souza, que deu à luz em uma cela de castigo na Penitenciária Feminina de Talavera Bruce, Rio de Janeiro, ver https://vozerio.org.br/Gravidas-no-carcere. Em relação aos "homens esmerdeados em celas de castigo", faço menção ao clássico livro de Allen Feldman (1991), já citado neste artigo, no qual o autor fala de situações de tortura a que os presos rebelados em uma prisão da Irlanda do Norte eram submetidos, ao mesmo tempo em que as subvertiam, na década de 1980. Cabe destacar aqui, que, certamente, a situação descrita por Allen Feldman não é exclusiva daquela década e daquele contexto prisional; é sintomático, porém, que não haja, com mesmo destaque, notícias voltadas para torturas que elucidem o sangue e a escatologia vivenciados pelos homens em celas de castigo $e$ situações de tortura nas prisões brasileiras.
} 
viver com a mãe ou com os filhos. Tantas outras coisas produziam o horizonte de preocupações das pessoas presas que a menstruação nunca, em nenhum momento, foi significativamente trazida para a pauta das nossas conversas nos pátios das unidades penitenciárias do estado de SP. Em anos de trabalho de campo, a única mulher que me falou sobre menstruação foi uma brasileira que passou dias presa no "calabouço do aeroporto" de Barcelona e que estava menstruada. Ela passou três dias isolada, sem outras companheiras de aprisionamento que pudessem ajudá-la, esperando para ser transferida para a penitenciária onde, enfim, pôde tomar banho.

A narrativa do "miolo de pão", referente a uma grave denúncia de tortura, passa a ser articulada nos âmbitos da razão humanitária do Estado, como um "mito da mulher presa", similar ao que Thaddeus Blanchette e Ana Paula Silva chamaram de "Mito de Maria", ou seja, a narrativa recorrente da mulher negra do "terceiro mundo" que ingenuamente é enredada pelas malhas do tráfico internacional de pessoas. Mito o qual, pela presunção protetiva às "vulneráveis" mulheres do "terceiro mundo", criminaliza a prostituição no Brasil e categoriza como "perigosos" os deslocamentos migratórios de mulheres e homens dos países do "Sul" para o "Norte" global.

Por mito, argumentam os autores, entende-se não histórias mentirosas que nunca tenham acontecido, mas sim a concepção acerca de um dado fenômeno de modo distorcido e idealizado sobre as fundamentações de estereótipos de classe, raça e gênero. A concepção emocional e política articulada a partir do "miolo de pão" sobre as "mulheres presas" reitera categorias de gênero que relacionam mulheres à maternidade - à menstruação - e, portanto, produzem suas "vulnerabilidades" desde especificidades vinculadas à reprodução e a demais atributos de gênero socialmente reconhecidos como "femininos". Assim como a música que Leci Brandão canta na ALESP, a mulher acionada pelo "miolo de pão" é vítima de suas relações com "homens opressores" que, se nessa narrativa são materializados pelo próprio "sistema prisional", nas falas das agentes da FUNAP que 
interditaram a minha entrada na prisão genérica masculina no ano de 2003, bem como na conexão com as redes de tráfico de mulheres, materializavam-se pela masculinidade negra $e$ "monstruosa" dos homens presos. Masculinidade e racialidade que, intersectadas, edificam a própria instituição prisional: um "dispositivo de segurança".

A "esposa do bandido bananão", por sua vez, não configura o sujeito do marco de inteligibidade da gramática do humanitarismo voltada para as "mulheres encarceradas". Sua narrativa é inaudita para o corpus dos repertórios humanitários voltados para as instituições punitivas femininas. A discrepância desse inaudito é o processo através do qual a prisão é produzida $e$ tramada como aparelho de Estado esquadrinhador (Foucault, 1979) dos sujeitos que prende, encarcera, despe e revista no cubículo onde repousa o velho espelho oxidado. Dito de outro modo, e ainda com base nas análises bibliográficas sobre razão humanitária do Estado, as "mulheres presas" pensadas como sujeitos universais e fora de suas redes relacionais, tramadas narrativamente como "vítimas" das opressões masculinas, são "despolitizadas" (Malkki, 1995) e configuradas em "corpos amorfos" (Mohanty, 1986) que enredam e reforçam a reiteração dos dispositivos de segurança os quais, por sua vez, recaem sobre o cotidiano de seus próprios corpos nos cubículos das revistas íntimas vexatórias das prisões.

Como Natália Lago (2017) e Rafael Godoi (2015) demonstram, as malhas que regulam visitas e portarias das prisões são majoritariamente compostas por mulheres. Não só pela presença significativamente superior de mulheres nas filas das visitas das prisões (femininas e masculinas); os autores demonstram que a administração dos transportes que levam familiares para as portas das unidades prisionais, bem como dos hotéis e hospedagens voltados para aquelas que têm de viajar quilômetros para visitarem filhos/filhas, esposos/esposas, irmãos/irmãs, pais/mães, é produzida como atribuição própria das "mulheres" que se relacionam com a instituição prisional. 
Se a prisão como instituição de Estado é genericamente reconhecida como masculina e negra - uma combinação monstruosamente vinculada às categorizações de violência sexual dos corpos femininos brancos e às opressões dos corpos femininos negros - são as suas fronteiras, suas portarias e checkpoints, produzidos através de práticas institucionais de violação $e$ penetração dos corpos das mulheres que lotam as filas das visitas familiares. São esses mesmos corpos que incham as penitenciárias femininas e que são articulados pelas retóricas da razão humanitária do Estado como "vulneráveis", corpos amorfos prérelacionais e subservientes aos monstruosos homens opressores: "os bandidos de verdade" dos quais, se não os homens brancos, as mulheres que ocupam as cadeiras da ALESP devem salvá-los, parafraseando Gayatri Spivak (2010).

Tal processo de despolitização e produção do corpo amorfo das "mulheres encarceradas" tornam inauditas as principais demandas por direitos cotidianamente repetidas por aquelas que cumprem pena nas prisões. Demandas referentes aos acessos à justiça - à informação de seus processos de execução criminal, a representações jurídicas competentes, bem como à crítica radical das tecnologias jurídico-policiais que as criminalizam $e$ criminalizam seus familiares: homens negros (Davis, 2003).

O exercício anedótico de olhar para o "tráfico de mulheres" nas portarias da prisão, ou seja, a análise da capilarização das narrativas de um "feminismo carcerário" emaranhado à "razão humanitária de Estado" que passa a localizar socialmente os homens presos como monstruosos $e$ as mulheres presas como oprimidas, configura a fissura entre vulnerabilidade e perigo a qual implica no efeito de edificação da prisão. Esta, nada genérica, que encarcera massivamente as populações socialmente categorizadas desde intersecções de gênero, raça e classe como "criminosas". Não por acaso, portanto, o mesmo corpo que, quando enredado a determinadas relações - com a universidade e com o "canônico" campo masculino de pesquisa acadêmica - é feminilizado e embranquecido, localizado numa "classe média" a ser protegida dos abusos dos homens negros presos é, ao ser emaranhado aos 
fluídos afetivos da prisão, enegrecido e penetrado pelo aparato da "segurança" do estado. Como fronteira, eu jamais poderia ser "pesquisadora, voluntária e família", as três coisas não podem ser.

Perante os aparatos de controle das entradas/saídas da prisão, ou se é um corpo amorfo ou um campo institucional imbuído da missão salvadora. O "anjo do progresso" é reatualizado na discursividade canônica da universidade também nada genérica, mas quase sempre branca e masculina. Perante os aparelhos de gestão estatal dos sujeitos e das relações com a prisão, corpos $e$ instituições só podem ser uma: branca ou preta, pesquisadora ou família, universidade ou prisão, vulnerável ou perigosa.

\section{Referências bibliográficas}

ABU-LughOD, Lila. Do Muslim Women Really Need Saving? Anthropological Reflections on Cultural Relativism and Its Others. American Anthropologist 104(3), 2002, pp.783-790.

ALVES, Enedina do Amparo. Rés negras, judiciário branco: uma análise da interseccionalidade de gênero, raça e classe na produção da punição em uma prisão paulistana. Dissertação (Mestrado em Ciências Sociais), Pontifícia Universidade Católica de São Paulo PUC-SP, 2015.

ANDRADE, Eliakim Lucena de. A rua dos irmãos: uma etnografia na prisão. Dissertação (Mestrado em Sociologia), Centro de Humanidades, Universidade Federal do Ceará, Fortaleza, 2014.

ANTUNES, Sara Vieira. Para habitar entre grades: táticas de [sobre]vida na prisão. Aracê: Direitos Humanos em Revista, vol. 4, n 5, 2017, pp.116-135.

BEAUVOIR, Simone. O segundo sexo: a experiência vivida. Vol. 2. São Paulo, Difusão Européia do Livro, 1967.

BERNSTEIN, Elizabeth. Militarized Humanitarianism Meets Carceral Feminism: The Politics of Sex, Rights, and Freedom in Contemporary Antitraficking Campaigns. Journal of Women in Culture and Society, vol. 36, n $1,2010$. 
BIRMAN, Patrícia; MACHADO, Carly. A violência dos justos: evangélicos, mídia e periferias da metrópole. Revista Brasileira de Ciências Sociais (RBCS), vol. 27, n 80, outubro 2012, pp.55-69.

BlanchetTe, Thaddeus; Silva, Ana Paula. O Mito de Maria, uma traficada exemplar: confrontando leituras mitológicas do tráfico com as experiências de migrantes brasileiros, trabalhadores do sexo. REMHU, vol. XIX, 2011, pp.79-106.

BRAH, Avtar. Diferença, diversidade, diferenciação. cadernos pagu (26), Campinas-SP, Núcleo de Estudos de Gênero-Pagu/Unicamp, janeirojunho, 2006, pp.329-376.

BRANT, Vinicius Caldeira. O trabalho encarcerado. Rio de Janeiro, Editora Forence, 1994.

BRASIL. Presidência da República. Casa Civil. Subchefia para Assuntos Jurídicos. Lei ${ }^{\circ} 7.210$, de 11 de julho de 1984. Texto compilado. Lei de Execução Penal.

BRASIL. Presidência da República Casa Civil Subchefia para Assuntos Jurídicos. Lei $\mathrm{n}^{\circ} 11.343$ de 23 de agosto de 2006. Texto Compilado. Lei do Sistema Nacional de Políticas Públicas sobre Drogas.

BRASIL. Presidência da República. Casa Civil. Subchefia para Assuntos Jurídicos. Lei $\mathrm{n}^{\circ}$ 13.344, de 6 de outubro de 2016. Texto Compilado. Lei de prevenção e repressão ao tráfico interno e internacional de pessoas.

BRASIL. Presidência da República. Casa Civil. Subchefia para Assuntos Jurídicos. Lei $n^{\circ}$ 13.445, de 24 de maio de 2017. Lei de Migração.

CARSten, Janet. After Kinship. Cambridge, The Press Syndicate of the University of Cambridge, 2004.

DAS, Veena. Critical Events: An Anthropological Perspective on Contemporary India. New Delhi, Oxford University Press, 1995.

; POOLE, Deborah. State and its margins: comparative ethnographies. In: DAS, Veena; POOLE, Deborah (org.). Anthropology in the margins of the State. Oxford, James Currency, 2004, pp.3-33.

Davis, Angela. "Race and Criminalization". In: LUBIANO, Wahneema (org.). The House That Race Buit. New York, Vintage Books, 1997, pp. 264-279. 
- How gender structures the prison system. In: Are Prisons Obsolete? New York, Seven Stories Press, 2003, pp.60-83.

. Mulheres, raça e classe. São Paulo, Boitempo, 2016.

DIAS, Camila Nunes. A igreja como refúgio e a Biblia como esconderijo: religião e violência na prisão. São Paulo, Humanitas, 2008.

DÍAZ-BENÍTEZ, Maria Elvira. Corpos e sexo bizarros; estéticas transgressoras no pornô. Relatório Final, projeto de pós-doutorado FAPESP vinculado ao Núcleo de Estudos de Gênero-Pagu/Unicamp, sob supervisão de Maria Filomena Gregori, 2013. (mimeo).

ESPINOZA, Olga. A mulher encarcerada em face do poder punitivo: o direito ao trabalho em uma prisão feminina. Dissertação (Mestrado em Direito). Faculdade de Direito, Universidade de São Paulo, São Paulo, 2003.

FASSIN, Didier. Humanitarian reason. A moral history of the present. Berkeley, University of California Press, 2011.

FELDMAN, Allen. Formations of violence: The narrative of the Body and Political Terror in Northern Ireland. Chicago, The University of Chicago Press, 1991.

FELTRAN, Gabriel. Fronteiras de tensão: política e violência nas periferias de São Paulo. São Paulo, Editora Unesp, CEM, Cebrap, 2011.

FERREIRA, Letícia Carvalho de Mesquita. "Apenas preencher papel": Reflexões sobre registros policiais de desaparecimento de pessoas $e$ outros documentos. Mana, 19(1), 2013, pp.39-68.

Foucault, Michel.. História da sexualidade: A vontade de Saber. Rio de Janeiro, Edições Graal, 1979.

FouCAUlT, Michel. Segurança, território e população: Curso dado no Collège de France (1977-1978). São Paulo, Martins Fontes, 2008.

GoDoI, Rafael. Ao redor e através da prisão: cartografias do dispositivo carcerário contemporâneo. Dissertação (Mestrado Sociologia), Faculdade de Filosofia Letras e Ciências Humanas, Universidade de São Paulo, 2010.

- Fluxos em cadeia: as prisóes em São Paulo na virada dos tempos. Tese (Doutorado Sociologia), Faculdade de Filosofia Letras e Ciências Humanas, Universidade de São Paulo, 2015. 
GREGORI, Maria Filomena. Prazeres perigosos: Erotismo, gênero e limites da sexualidade. São Paulo: Companhia das Letras. 2016.

GREWAL, Inderpal; KAPLAN, Caren. Introduction: Transnational Feminist Practicies and Questions of Postmodernity. In: GREWAL, Inderpal; KAPLAN, Caren (org.). Scattered hegemonies: postmodernity and transnational feminist practicies. Minneapolis, Minnesota, University of Minnesota Press, 1999.

HIRATA, Helena. A precarização e a divisão internacional e sexual do trabalho. In: Sociologias, vol. 21, janeiro/junho, 2009, pp.24-41.

Kempadoo, Kamala. Sexing the Caribbean. Gender, Race and Sexual Labour. Abingdon, Routledge. 2004.

KleInMAn, Arthur. What Really Matters: Living a Moral Life Amidst Uncertainty and Danger. New York, Oxford University Press, 2006.

JEGANATHAN, Pradeep. Checkpoint: anthropology, identity, and the state. In: DAS, Veena; PoOLE, Deborah (ed.). Anthropology in the margins of the state. Santa Fe, School of American Research Press, 2004, pp.67-80.

LAGO, Natália Bouças do. Mulheres na prisão: Entre famílias, batalhas e a vida normal. Dissertação (Mestrado Antropologia Social), Faculdade de Filosofia Letras e Ciências Humanas, Universidade de São Paulo, 2014.

. Nem dentro, nem fora: Gênero, trânsitos e associações de mulheres que circulam pela prisão. Relatório apresentado para exame de qualificação no doutorado em Antropologia Social. Faculdade de Filosofia Letras e Ciências Humanas, Universidade de São Paulo 2017. (mimeo).

LAURETIS, Teresa de. A tecnologia do gênero. In: Holanda, Heloísa Buarque de. Tendencias e impasses: o feminismo como crítica da cultura. Rio de Janeiro, Iser, 1994, pp.206-242.

LECI Brandão. O bagulho do amante. Eu e o samba. Rio de Janeiro, 2008.

LOWENKRON, Laura. O monstro contemporâneo: a construção social da pedofilia em múltiplos planos. Rio de Janeiro, Eduerj, 2015a. 
- Consentimento e vulnerabilidade: alguns cruzamentos entre o abuso sexual infantil e o tráfico de pessoas para fim de exploração sexual. cadernos pagu (45), Campinas-SP, julho-dezembro, 2015b, pp. 225-258.

; FERREIRA, Letícia. Anthropological perspectives on documents: Ethnographic dialogues on the trail of police papers. Vibrant, vol. 11 $\mathrm{n}^{\circ} 2$, 2014, pp.75-111.

MCCLINTOCK, Anne. Couro Imperial: Raça, gênero e sexualidade no embate colonial. Campinas-SP, Editora da Universidade da Unicamp. 2010.

MAHLER, Sarah J.; PESSAR, Patricia R. Gendered geographies of power: Analyzing gender across transnational spaces. Identities, 7(4), 2001, pp.441-459.

MAHMOOD, Saba. Feminist Theory, Embodiment, and the Docile Agent: Some Reflections on the Egyptian Islamic Revival. Cultural Anthropology, 16(2), 2001, pp.202-236.

MALKKI, Liisa. Refugees and Exile: From "Refugee Studies" to the National Order of Things. Annual Review of Anthropology, vol. 24, 1995, pp.495-523 [http://www.jstor.org/stable/2155947 - acesso em: 25 nov. 2017].

MARQUES, Vagner Aparecido. $O$ irmão que virou irmão: rupturas $e$ permanências na conversão de membros do PCC ao pentecostalismo na Vila Leste - SP. Dissertação (Mestrado em Ciências da Religião), Programa de Pós-Graduação em Ciências da Religião, Pontifícia Universidade Católica de São Paulo / PUC-SP, 2013.

MINISTÉRIO da Justiça. Departamento Penitenciário Nacional. Cartilha dos Conselhos da Comunidade / Comissão para Implementação e Acompanhamento dos Conselhos da Comunidade. Brasília, Artecor Gráfica e Editora, 2008.

MOHANTY, Chandra Talpade. 1986. Under Western Eyes: Feminist Scholarship and Colonial Discourses. Boundary 2 12(3), 1986, pp.333-358.

MouTinHO, Laura. Raça, "cor" e desejo: Uma análise comparativa sobre relacionamentos afetivo-sexuais "inter-raciais" no Brasil e na África do Sul. São Paulo, Editora UNESP, 2004. 
NADAI, Larissa. Descrever crimes, decifrar convenções narrativas: uma etnografia entre documentos oficiais da Delegacia de Defesa da Mulher de Campinas em casos de estupro e atentado violento ao pudor. Dissertação (Mestrado Antropologia Social), Instituto de Filosofia e Ciências Humanas, Universidade Estadual de Campinas, 2012.

PADOVANI, Natália Corazza. A natureza da qualidade: considerações acerca das diferenças de gênero no trabalho prisional., Revista de Sociologia Jurídica 3, julho/dezembro, 2006, Revista eletrônica. [https://sociologiajuridicadotnet.wordpress.com/a-natureza-daqualidade-consideracoes-acerca-das-diferencas-de-genero-notrabalho-prisional/ - acesso em: 25 nov. 2017].

"Perpétuas Espirais": Falas do poder e do prazer sexual em trinta anos (1977-2009) na história da Penitenciária Feminina da Capital. Dissertação (Mestrado em Sociologia), Instituto de Filosofia e Ciências Humanas, Universidade Estadual de Campinas, 2010.

Sobre casos e casamentos: Das redes de afetos e dos relacionamentos amorosos através das penitenciárias femininas das cidades de São Paulo e Barcelona. Tese (Doutorado em Antropologia Social), Instituto de Filosofia e Ciências Humanas, Universidade Estadual de Campinas, 2015.

PEIRANO, Mariza. Identifique-se! O caso Henry Gates versus James Crowley como exercício antropológico, Revista Brasileira de Ciências Sociais, vol. 26, n 77, São Paulo, 2011, pp.63-77.

PISCITELli, Adriana Gracia. Amor, apego e interesse: trocas sexuais, afetivas em cenários transnacionais. In: PISCITELLI, Adriana; ASSIS, Glaucia Oliveira de; Olivar, José Miguel (ed.) Gênero, sexo, amor e dinheiro: mobilidades transnacionais envolvendo o Brasil. CampinasSP, Pagu/Unicamp, 2011, pp.385-433 (Coleção Encontros).

. Trânsitos: brasileiras nos mercados transnacionais do sexo. Rio de Janeiro, EdUERJ. 2013.

; LOWENKRON, Laura. Categorias em movimento: a gestão de vítimas do tráfico de pessoas na Espanha e no Brasil. Deslocamentos. Ciência e Cultura, Revista da SPBC, vol. 67, n 2, São Paulo, 2015, pp.35-39. 
QuinAlHA, Renan. Presa, negra e travesti: devemos ser todas Verônica. Ponte Jornalismo, 15 abr. 2015 [http://ponte.org/presa-negra-etravesti-devemos-ser-todas-veronica/ - acesso em: 25 nov. 2017].

Ramalho, José Ricardo. Mundo do Crime. A Ordem pelo Avesso. Rio de Janeiro, Edições Graal. 1979.

REDE Justiça Criminal. Boletim temático: revista vexatória, Informativo Rede Justiça

Criminal, 2014 [http://www.conectas.org/arquivos/editor/files/Informativo JusticaCrim inal 6 2014\%20\%281\%29.pdf - acesso em: 25 nov. 2017].

Salla, Fernando. As prisões em São Paulo (1822-1940). São Paulo, Annablume, 1999.

SÃo Paulo. Secretaria de Administração Penitenciária. Regimento Interno Padrão dos Estabelecimentos Prisionais do Estado de São Paulo [http://www.funap.sp.gov.br/site/ - acesso em 25 nov. 2017].

SPIVAK, Gayatri. Pode o subalterno falar? Belo Horizonte, Editora UFMG, 2010.

STRATHERn, Marilyn. O Gênero da Dádiva: Problemas com as mulheres e problemas com a sociedade na Melanésia. Campinas-SP, Editora Universidade Estadual de Campinas, 2010.

VIANNA, Adriana. Introdução: fazendo e desfazendo inquietudes no mundo dos direitos. In: VIANNA, Adriana (org.). O fazer e o desfazer direitos: Experiências etnográficas sobre política, administração $e$ moralidades. Rio de Janeiro, e-papers, 2013, pp. 14-35.

- Etnografando documentos: uma antropóloga em meio a processos judiciais. In: CASTILHO, Ricardo Rodrigues; LIMA, Antônio Carlos de Souza; TeIXEIRA, Carla Costa (org.). Antropologias das práticas de poder: reflexões etnográficas entre burocratas, elites $e$ corporações. Rio de Janeiro, Contra Capa, FAPERJ, 2014, pp.43-70. 